\title{
PEMBUATAN ARANG AKTIF DARI TEMPURUNG KELAPA SAWIT DAN SERBUK KAYU GERGAJIAN CAMPURAN
}

\author{
(The Manufacture of Activated Charcoal from Oil Palm Shells and \\ Mixture of Wood Sawdust)
}

Oleh/By :

Djeni Hendra ${ }^{1)}$

\begin{abstract}
This topic pertains to the experiment results of activated charcoal manufacture using raw material from oil palm shell and a mixture of wood sawdusts with employing steam activation. This experiment aimed to look for an appropriate alternative utilization of wastes from palm oil mill and sawmill into useful products with economical added values. The manufacture of activated charcoal took place in a retort constructed from stainless steel equipped with electric elements and proceeded at three temperature levels (i.e. 650, 750 and $850^{\circ} \mathrm{C}$ ). Activators used in this experiment was H3PO4 solution in three concentrations (i.e. 7.5, 10.0 and $12.5 \%$ ).

The results revealed that the optimum condition to achieve best quality activated charcoal prepared from mixed sawdusts was at $850^{\circ} \mathrm{C}$ and $12.5 \% \mathrm{H} 3 \mathrm{PO}$. Further such, the condition afforded the activated charcoal yield at $63.3 \%$, its moisture content $7.90 \%$, ash content $8.04 \%$, volatile matter $11.50 \%$, fixed carbon content $79.86 \%$, adsorption on benzene $28.43 \%$, adsorption on iod $1107.43 \mathrm{mg} / \mathrm{g}$. The activated charcoal prepared from oil palm shell that employed the particular condition (i.e. $650^{\circ} \mathrm{C}$ and $7.5 \% \mathrm{H} 3 \mathrm{PO} 4$ ) afforded the yield at $80 \%$, its moisture content $5.30 \%$, ash content $5.44 \%$, volatile matter $11.30 \%$, fixed carbon $83.74 \%$, adsorption on benzene $26.23 \%$, and adsorption on iodine $1045.27 \mathrm{mg} / \mathrm{g}$. Such adsorption figures on benzene and iodine could comply with the Indonesian and Japanese Standards.
\end{abstract}

Keywords: Oilpalm shell, wood sawdust, activated charcoal, benzene, iodine.

\begin{abstract}
ABSTRAK
Tulisan ini menyajikan hasil penelitian pembuatan arang aktif dari tempurung kelapa sawit dan serbuk kayu gergajian campuran dengan cara aktivasi uap. Tujuan dari penelitian ini adalah untuk mencari alternative pemanfaatan limbah dari pabrik minyak kelapa sawit dan serbuk kayu gergajian
\end{abstract}

${ }^{1)}$ Peneliti pada Pusat Penelitian dan Pengembangan Hasil Hutan, Bogor 
menjadi arang aktif yang dapat memberikan nilai tambah. Proses pembuatan arang aktif dilakukan dengan menggunakan retort dari baja tahan karat yang dilengkapi dengan elemen listrik pada suhu 650, 750 dan $850^{\circ} \mathrm{C}$. Sebagai bahan pengaktif digunakan larutan H3PO4 dengan konsentrasi masingmasing $7,5,10,0$ dan $12,5 \%$.

Kondisi optimum untuk membuat arang aktif dengan kualitas terbaik dihasilkan dari arang aktif yang dibuat dari bahan baku serbuk kayu gergajian campuran pada suhu $850^{\circ} \mathrm{C}$ dengan konsentrasi H3PO4 12,5\% menghasilkan rendemen arang aktif sebesar 63,3\%, kadar air 7,90\%, kadar abu 8,04\%, kadar zat mudah menguap $11,50 \%$, kadar karbon terikat $79,86 \%$, daya serap benzena $28,43 \%$ dan daya serap terhadap yodium sebesar $1.107,43 \mathrm{mg} / \mathrm{g}$. Sedangkan arang aktif yang dibuat dari bahan baku tempurung kelapa sawit pada suhu 6500C dengan konsentrasi H3PO4 7,5\% menghasilkan rendemen arang aktif sebesar $80 \%$, kadar air 5,30\%, kadar abu 5,44\%, kadar zat mudah menguap $11,30 \%$, kadar karbon terikat $83,74 \%$, daya serap terhadap benzena $26,23 \%$ dan daya serap terhadap yodium sebesar $1.045,27 \mathrm{mg} / \mathrm{g}$. Angka daya serap benzena dan yodium ini memenuhi Standar Indonesia dan Jepang.

Kata kunci : Tempurung kelapa sawit, serbuk kayu gergaiian campuran, arang aktif, benzena, yodium.

\section{PENDAHULUAN}

Arang aktif adalah arang yang konfigurasi atom karbonnya dibebaskan dari ikatan dengan unsur lain, serta pori dibersihkan dari senyawa lain se-hingga permukaan dan pusat aktif menjadi luas akibatnya daya adsorbsi terhadap cairan atau gas akan meningkat. Sesuai penggunaannya, arang aktif digolongkan ke dalam produk kimia dan bukan bahan energi seperti arang atau briket arang. Teknologi olah lanjut arang menjadi arang aktif akan memberikan nilai tambah yang besar ditinjau dari penggunaan dan nilai ekonomisnya.

Di Indonesia bahan baku untuk membuat arang aktif sebagian besar menggunakan tempurung kelapa dan kayu. Di lain pihak bahan baku yang dapat dibuat menjadi arang aktif adalah semua bahan yang mengandung karbon, baik yang berasal dari tumbuh-tumbuhan, binatang, maupun barang tambang seperti batu bara. Bahan-bahan tersebut adalah berbagai jenis kayu, sekam padi, tulang binatang, batu bara, tempurung kelapa, kulit biji kopi, bagase, dan lain-lain. Akhir-akhir ini arang aktif dibuat dari bahan baku polimer seperti poliakrilonitril, rayon dan resol fenol (Hoyashi et al., 1984 dalam Hendra dkk., 1999).

Dalam penelitian ini proses aktivasi dilakukan dengan cara mengalirkan gas panas hasil penguraian larutan H3PO4, sehingga dapat lebih meningkatkan kualitas arang aktif. Penelitian ini bertujuan untuk mencari alternatif pemanfaatan tempurung kelapa sawit dari limbah pabrik pengolahan minyak sawit dan serbuk kayu gergajian campuran dari limbah pabrik gergajian kayu secara optimal dan ekonomis, mengingat potensi yang cukup besar dan belum dimanfaatkan dengan optimal.

\section{METODOLOGI}

\section{A. Bahan}

Bahan yang digunakan pada penelitian ini adalah tempurung kelapa sawit dari limbah pabrik pengolahan minyak sawit yang terdapat di Malingping Banten Selatan, dan serbuk gergaji campuran kayu diperoleh dari Laboratorium Penggergajian Pusat Penelitian dan 
Pengembangan Hasil Hutan Bogor. Bahan kimia yang digunakan adalah asam fosfat (H3PO4) sebagai bahan pengaktif, benzena dan yodium untuk penetapan besarnya daya serap terhadap gas dan larutan.

\section{B. Metode}

Bahan baku tempurung kelapa sawit dan serbuk kayu gergaji cam-puran kayu dijemur di udara terbuka sampai mencapai kadar air kering udara. Selanjutnya serbuk yang dihasilkan terlebih dahulu dicampur dengan $2 \%$ perekat kanji dan kemudian dibuat briket dengan alat kempa khusus pada tekanan 5 ton untuk 20 lubang dengan diameter 1,0 cm. Serbuk yang sudah dibentuk briket dimasukkan ke dalam retort listrik dan dipanaskan pada tingkatan suhu 650,750 dan $850^{\circ} \mathrm{C}$ dan selanjutnya diaktivasi.

Proses aktivasi dilakukan dengan cara mengalirkan gas panas hasil penguraian larutan H3PO4 masing-masing dengan konsentrasi 7,5; 10 dan 12,5\% selama 90 menit pada laju alir gas sebesar 0,05 kg/jam (Gambar 1). Kualitas arang aktif yang diuji, yaitu rendemen, kadar air, abu, zat terbang, karbon, daya serap terhadap yodium dan benzena. Kualitas arang aktif yang terbaik diuji cobakan untuk membersihkan dan menjernihkan air sumur yang berwarna kuning, dan air yang telah dijernihkan diuji kualitasnya dengan cara dianalisa warna, $\mathrm{pH}$ dan kandungan logam Fe, Zn dan Mn menurut prosedur yang ditetapkan Anonim (1990).

Untuk mengetahui adanya pengaruh bahan pengaktif dan konsentrasi bahan kimia terhadap kualitas arang aktif dilakukan perhitungan statistik dengan rancangan percobaan yang digunakan adalah rancangan acak lengkap $(2 \times 3 \times 3)$ dengan 3 kali ulangan (Sudjana, 
- Tempurung kelapa sawit (Palm oil shell)

- Serbuk gergaji campuran kayu (Mixed of wood sawdust)
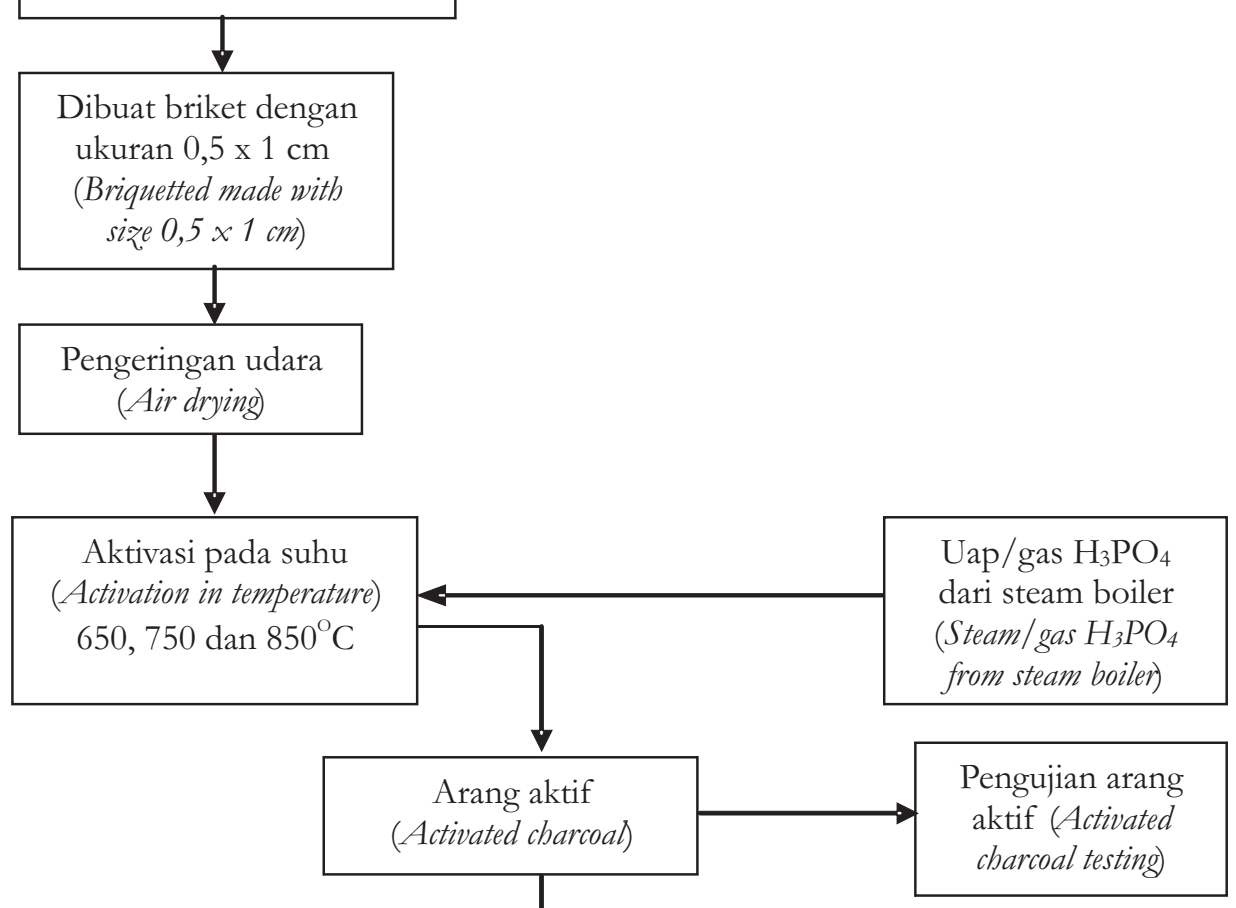

Gambar 1. Diagram alir proses pembuatan arang aktif Figure 1. Flow diagram of activated charcoal manufacture 


\section{HASIL DAN PEMBAHASAN}

\section{A. Rendemen Arang Aktif}

Rendemen arang aktif yang diperoleh dari arang tempurung kelapa sawit dan arang serbuk gergaji campuran kayu yang diaktivasi dengan menggunakan retort dari baja tahan karat yang dilengkapi dengan pemanas listrik, berkisar antara 64 - 86,7\%, sedangkan rendemen arang aktif dari serbuk gergaji campuran kayu berkisar antara 56 - 85,3\% (Tabel 1).

\section{Tabel 1. Rendemen arang aktif}

\section{Table 1. Yield of activated charcoal}

\begin{tabular}{|c|c|c|c|c|}
\hline No. & $\begin{array}{l}\text { Bahan baku } \\
\text { (Raw material) }\end{array}$ & $\mathrm{H}_{3} \mathrm{PO}_{4}(\%)$ & $\begin{array}{c}\text { Suhu } \\
\text { (Temperature), }{ }^{\mathrm{O} C}\end{array}$ & $\begin{array}{l}\text { Rendemen } \\
\text { (Yield), \% }\end{array}$ \\
\hline \multirow[t]{9}{*}{1} & \multirow{9}{*}{$\begin{array}{l}\text { Arang tempurung kelapa sawit } \\
\text { (Charcoal from oil palm shell) }\end{array}$} & 7,5 & 650 & 80 \\
\hline & & & 750 & 84 \\
\hline & & & 850 & 72,7 \\
\hline & & 10 & 650 & 85,3 \\
\hline & & & 750 & 86,7 \\
\hline & & & 850 & 64 \\
\hline & & 12,5 & 650 & 77,3 \\
\hline & & & 750 & 69,3 \\
\hline & & & 850 & 79,3 \\
\hline \multirow[t]{9}{*}{2} & \multirow{9}{*}{$\begin{array}{l}\text { Arang serbuk gergaji campuran } \\
\text { kayu (Charcoal from mixture of } \\
\text { sawdust) }\end{array}$} & 7,5 & 650 & 85,3 \\
\hline & & & 750 & 77,3 \\
\hline & & & 850 & 56 \\
\hline & & 10 & 650 & 76,7 \\
\hline & & & 750 & 63,3 \\
\hline & & & 850 & 68,7 \\
\hline & & 12,5 & 650 & 81,3 \\
\hline & & & 750 & 84,7 \\
\hline & & & 850 & 63,3 \\
\hline
\end{tabular}

Rendemen arang aktif dari arang tempurung kelapa sawit tertinggi adalah yang diaktivasi dengan $\mathrm{H} 3 \mathrm{PO} 410 \%$ pada suhu $750^{\circ} \mathrm{C}$, sedangkan rendemen arang aktif tertinggi dari arang serbuk gergaji campuran kayu adalah yang diaktivasi dengan H3PO4 7,5\% pada suhu $650^{\circ} \mathrm{C}$. Namun, rendemen arang aktif dari serbuk gergaji campuran kayu lebih rendah dibandingkan dengan rendemen arang aktif tempurung kelapa sawit. Hal ini disebabkan karena struktur tempurung kelapa sawit relatif lebih padat, walaupun tidak terlalu keras, sehingga menghasilkan arang yang sulit diaktivasi. 
Tabe12. Sidik ragam sifat arang aktif dari tempurung kelapa sawit dan serbuk gergaji campuran kayu

Table 2. Analysis of variance on the activated carbon properties from coconut shell and the mixture of wood sawdust

\begin{tabular}{|c|c|c|c|c|c|c|c|c|c|c|}
\hline \multirow{2}{*}{ No } & \multirow{2}{*}{ Sifat (Properties) } & \multicolumn{7}{|c|}{ Perlakuan (Treatment) } & \multirow{2}{*}{$\begin{array}{l}\text { Kuadrat } \\
\text { Tengah } \\
\text { (Mean } \\
\text { square) } \\
\end{array}$} & \multirow[t]{2}{*}{$\begin{array}{l}\text { F-Hitung } \\
\text { (F-calculated) }\end{array}$} \\
\hline & & $\mathrm{A}$ & B & $\mathrm{C}$ & $\mathrm{D}$ & $\mathrm{E}$ & F & G & & \\
\hline 1 & $\begin{array}{l}\text { Kadar air } \\
\text { (Moisture content), \% }\end{array}$ & 0.642 & 6.182 & 113.19 & 6.306 & 8.092 & 87.989 & 70.539 & 17.232 & 72.313 \\
\hline 2 & $\begin{array}{l}\text { Kadar abu } \\
\text { (Ash conTent), \% }\end{array}$ & 71.899 & 5.711 & 21.519 & 8.198 & 12.924 & 6.563 & 26.753 & 9.033 & 13.25 \\
\hline 3 & $\begin{array}{l}\text { Kadar zat menguap } \\
\text { (Volatike matter), \% }\end{array}$ & 32.325 & 4.971 & 21.608 & 11.968 & 18.056 & 30.943 & 6.531 & 7.435 & 12.27 \\
\hline 4 & $\begin{array}{l}\text { Kadar karbon terikat } \\
\text { (Fixed carbon), \% }\end{array}$ & 296.36 & 61.212 & 32.315 & 8.720 & 6.993 & 133.01 & 15.744 & 32.609 & 25.17 \\
\hline 5 & $\begin{array}{l}\text { Daya serap thd } \\
\text { benzene } \\
\text { (Absorp capacity of } \\
\text { benzene), \% }\end{array}$ & 33.923 & 378.33 & 262.01 & 617.16 & 14.891 & 356.89 & 127.79 & 105.354 & 377.01 \\
\hline 6 & $\begin{array}{l}\text { Daya serap thd } \\
\text { yodium } \\
\text { (Absorp capacity of } \\
\text { Iodine), \% }\end{array}$ & 2832.5 & 81333. & 41114 & 18889. & 208284 & 131633 & 122222 & 35665 & 7246.0 \\
\hline
\end{tabular}

Keterangan (Remarks): A = Bahan baku (Raw material); B = Konsentrasi pengaktif (Activation concentration); $\mathrm{C}=\mathrm{Suhu}$ (Temperature); $\mathrm{D}=$ Interaksi bahan baku dan konsentrasi pengaktif (Interaction of raw material and activation concentration); $\mathrm{E}=$ Interaksi bahan baku dan suhu (Interaction of raw material and temperature interaction); $\mathrm{F}=$ Interaksi konsentrasi pengaktif dan suhu (Interaction of activated concentration and temperature); $\mathrm{G}=$ Interaksi bahan baku, konsentrasi pengaktif dan suhu (Interaction of raw material, activation concentration and temperature).

\section{B. Kadar Air}

Berdasarkan analisa sidik ragam (Tabel 2) diketahui bahwa kon-sentrasi H3PO4 dan suhu aktivasi memberikan pengaruh yang nyata terhadap kadar air arang aktif.

Pada Tabel 3 terlihat bahwa kadar air arang aktif dari tempurung kelapa sawit terendah $(5,31 \%)$ terdapat pada arang aktif yang diaktivasi dengan $\mathrm{H} 3 \mathrm{PO} 47,5 \%$ pada suhu $650^{\circ} \mathrm{C}$, sedangkan kadar air tertinggi (13,06\%) dengan konsentrasi $\mathrm{H} 3 \mathrm{PO} 47,5 \%$ pada suhu $850^{\circ} \mathrm{C}$. Kadar air arang aktif dari serbuk gergaji campuran kayu terendah (4,87\%) terdapat pada arang aktif yang diberi perlakuan konsentrasi H3PO4 7,5\% pada suhu $650^{\circ} \mathrm{C}$, sedangkan kadar air arang aktif $(12,3 \%)$ tertinggi terdapat pada kombinasi perlakuan konsentrasi H3PO4 7,5\%, pada suhu $850^{\circ} \mathrm{C}$. Kadar air arang aktif yang dihasilkan dari semua kombinasi memenuhi syarat Standar Nasional Indonesia karena kadar air arang aktif tidak lebih dari 15\% (Anonim, 1995). Kadar air arang aktif pada serbuk gergaji campuran kayu lebih baik dari tempurung kelapa sawit, karena arang aktif tempurung kelapa sawit lebih banyak menyerap uap air dari udara pada waktu proses pendinginan. 
Kombinasi perlakuan terbaik untuk menghasilkan arang aktif dari tempurung kelapa sawit yaitu aktivasi yang dilakukan dengan menggunakan konsentrasi H3PO4 10\% pada suhu $850^{\circ} \mathrm{C}$, sedangkan untuk serbuk gergaji campuran kayu, dengan menggunakan konsentrasi H3PO4 $7,5 \%$ pada suhu $850^{\circ} \mathrm{C}$.

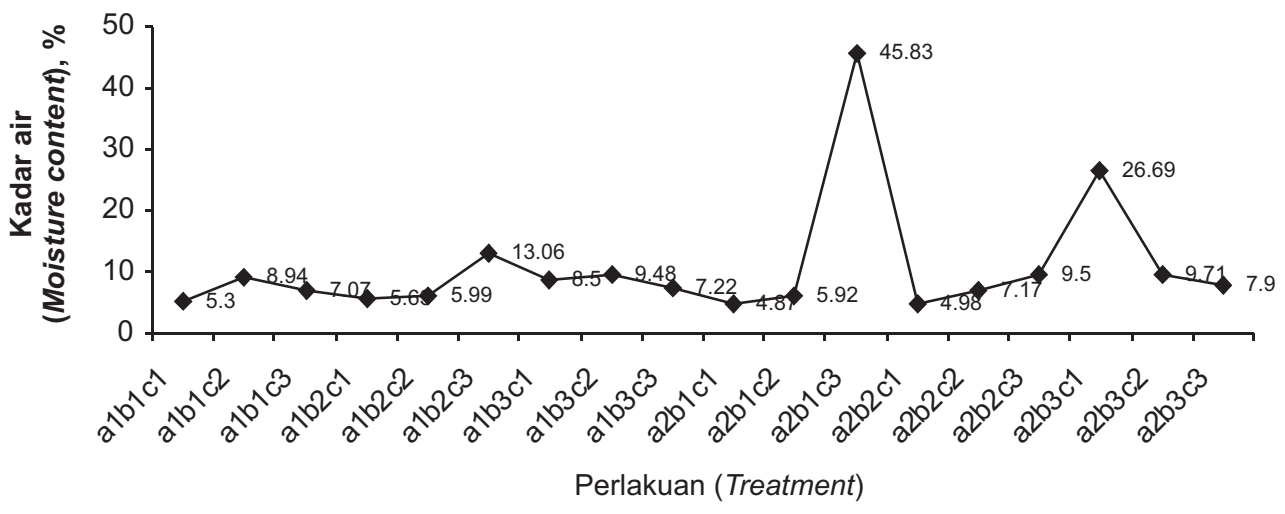

\section{Gambar 2. Interaksi antara perlakuan dengan kadar air Figure 2. Interaction between treatments and moisture content}

Keterangan (Remarks) $:$ a1 $=$ Arang tempurung kelapa sawit (Charcoal from 0il palm shell); a2 = Arang serbuk kayu gergajian campuran (Charcoal from mixture of sawdust); b1 = Konsentrasi $\mathrm{H}_{3} \mathrm{PO}_{4}$ 7,5\% (Concentrations phosphoric acid 7.5\%); b2 = Konsentrasi $\mathrm{H}_{3} \mathrm{PO}_{4} \quad 10 \%$ (Concentrations phosphoric acid 10\%); b3 = Konsentrasi $\mathrm{H}_{3} \mathrm{PO}_{4} 12,5 \%$ (Concentrationsphosphoric acid $12.5 \%) ; \mathrm{c} 1=\operatorname{Suhu} 650^{\circ} \mathrm{C}\left(\right.$ Temperature $\left.650^{\circ} \mathrm{C}\right) ; \mathrm{c} 2=\operatorname{Suhu} 750^{\circ} \mathrm{C}\left(\right.$ Temperature $\left.750^{\circ} \mathrm{C}\right)$; c3 $=$ Suhu $850^{\circ} \mathrm{C}\left(\right.$ Temperature $\left.850^{\circ} \mathrm{C}\right)$.

\section{Kadar Abu}

Analisa sidik ragam (Tabel 2) menunjukkan bahwa faktor bahan baku, konsentrasi bahan kimia dan konsentrasi suhu memberikan pengaruh yang nyata pada kadar abu yang dihasilkan.

Kadar abu (Tabel 3) yang dihasilkan pada penelitian ini menunjukkan bahwa untuk arang aktif tempurung kelapa sawit, kadar abu tertinggi (8,44\%) terdapat pada arang aktif yang diaktivasi dengan $\mathrm{H}_{3} \mathrm{PO}_{4} 12,5 \%$ pada suhu $850^{\circ} \mathrm{C}$, sedangkan kadar abu terendah $(4,55 \%)$ terdapat pada arang aktif yang diaktivasi dengan $\mathrm{H}_{3} \mathrm{PO}_{4} 10 \%$ pada suhu $850^{\circ} \mathrm{C}$. Kadar abu ini tidak memenuhi kualitas arang aktif yang ditetapkan Standar Nasional Indonesia (Anonim, 1995). Sedangkan kadar abu arang aktif dari serbuk gergaji campuran kayu tertinggi $(11,1 \%)$ terdapat pada arang aktif yang diaktivasi dengan menggunakan $\mathrm{H}_{3} \mathrm{PO}_{4}$ $7,5 \%$ pada suhu $850^{\circ} \mathrm{C}$, dan kadar abu terendah $(6,3 \%)$ terdapat pada arang aktif yang diaktivasi dengan $\mathrm{H}_{3} \mathrm{PO}_{4} 7,5 \%$ pada suhu $750^{\circ} \mathrm{C}$. Kadar abu dari arang aktif serbuk gergaji campuran kayu ini memenuhi kualitas arang aktif yang ditetapkan Standard Nasional Indonesia yaitu maksimum 10\%. (Anonim, 1995). 
Tabel 3. Sifat arang aktif

Table 3. Properties of activated charcoal

\begin{tabular}{|c|c|c|c|c|c|c|}
\hline \multirow{2}{*}{$\begin{array}{l}\text { Bahan baku } \\
\text { (Raw materiad) }\end{array}$} & \multirow{2}{*}{$\begin{array}{c}\mathrm{H}_{3} \mathrm{PO}_{4} \\
(\%)\end{array}$} & \multirow{2}{*}{$\begin{array}{c}\text { Suhu } \\
\text { (Temperature), } \\
{ }^{\circ} \mathrm{C}\end{array}$} & \multicolumn{4}{|c|}{$\begin{array}{c}\text { Sifat arang aktif } \\
\text { (Properties of activated charcoal), } \%\end{array}$} \\
\hline & & & A & B & $\mathrm{C}$ & $\mathrm{D}$ \\
\hline \multirow{9}{*}{$\begin{array}{l}\text { Arang tempurung } \\
\text { kelapa sawit } \\
\text { (Charcoal from oil } \\
\text { palm shell) }\end{array}$} & 7,5 & 650 & 5,30 & 5,44 & 11,30 & 83,74 \\
\hline & & 750 & 8,94 & 5,73 & 10,48 & 85,39 \\
\hline & & 850 & 7,07 & 5,05 & 12,98 & 81,06 \\
\hline & 10 & 650 & 5,63 & 4,85 & 12,31 & 81,80 \\
\hline & & 750 & 5,99 & 4,75 & 12,14 & 82,58 \\
\hline & & 850 & 13,06 & 6,05 & 10,00 & 83,45 \\
\hline & 12,5 & 650 & 8,50 & 4,55 & 9,67 & 86,62 \\
\hline & & 750 & 9,48 & 6,58 & 9,14 & 84,81 \\
\hline & & 850 & 7,22 & 8,44 & 10,92 & 82,66 \\
\hline \multirow{10}{*}{$\begin{array}{l}\text { Arang serbuk } \\
\text { kayu gergajian } \\
\text { campuran } \\
\text { (Charcoal from } \\
\text { mixture of sawdust) }\end{array}$} & 7,5 & 650 & 4,87 & 8,45 & 13,08 & 77,71 \\
\hline & & 750 & 5,92 & 6,30 & 11,09 & 81,41 \\
\hline & & 850 & 45,83 & 11,1 & 12,72 & 81,06 \\
\hline & & & & & & \\
\hline & 10 & 650 & 4,98 & 8,49 & 15,23 & 76,07 \\
\hline & & 750 & 7,17 & 6,71 & 11,74 & 77,76 \\
\hline & & 850 & 9,50 & 7,65 & 10,70 & 81,04 \\
\hline & 12,5 & 650 & 26,69 & 8,23 & 14,29 & 81,28 \\
\hline & & 750 & 9,71 & 7,22 & 12,53 & 81,15 \\
\hline & & 850 & 7,90 & 8,04 & 11,50 & 79,86 \\
\hline $\begin{array}{l}\text { Standar Nasional } \\
\text { Indonesia } \\
\text { (Indonesia } \\
\text { National Standard) }\end{array}$ & & & Maks. 15 & Maks. 10 & Maks. 25 & Min. 65 \\
\hline
\end{tabular}

Keterangan (Remarks) : A = Kadar air, \% (Moisture content, \%); B = Kadar abu, \% (Ash content, \%); C = Kadar zat terbang, \% (Volatile matter, \%); D = Kadar karbon, \% (Fixed carbon, \%). 
Kombinasi perlakuan terbaik untuk tempurung kelapa sawit adalah yang diaktivasi dengan $\mathrm{H}_{3} \mathrm{PO}_{4} 12,5 \%$ pada suhu $850^{\circ} \mathrm{C}(\mathrm{a} 1 \mathrm{~b} 3 \mathrm{c} 3)$, sedangkan untuk serbuk gergaji campuran kayu, adalah yang diaktivasi dengan $\mathrm{H}_{3} \mathrm{PO}_{4} 7,5 \%$ pada suhu $750^{\circ} \mathrm{C}$ (a2b1c2).

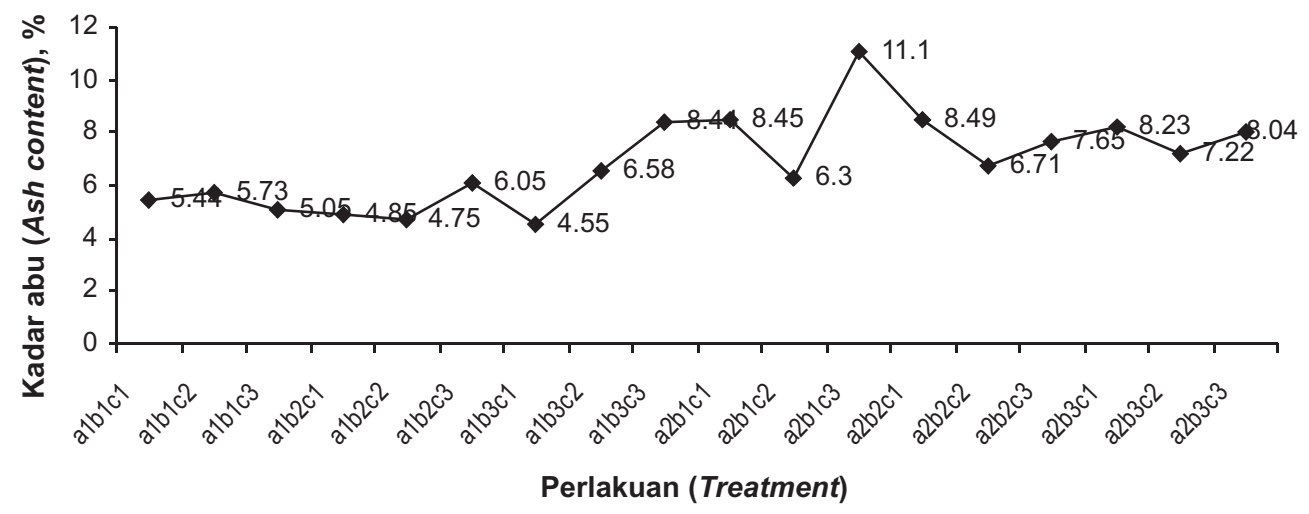

\title{
Gambar 3. Interaksi antara perlakuan dengan kadar abu Figure 3. Interaction betwen treatments and asb content
}

\begin{abstract}
Keterangan (Remarks) : a1 = Arang tempurung kelapa sawit (Charcoal from oil palm shell); a2 = Arang serbuk kayu gergajian campuran (Charcoal from mixture of sawdust); b1 = Konsentrasi $\mathrm{H}_{3} \mathrm{PO}_{4} \quad 7,5 \%$ (Concentrations phosphoric acid 7.5\%); b2 $=$ Konsentrasi $\mathrm{H}_{3} \mathrm{PO}_{4} \quad 10 \%$ (Concentrationsphosphoric acid 10\%); b3 = Konsentrasi $\mathrm{H}_{3} \mathrm{PO}_{4} 12,5 \%$ (Concentrationsphosphoric acid 12.5); $\mathrm{c} 1=\operatorname{Suhu} 650^{\circ} \mathrm{C}\left(\right.$ Tem-perature $\left.650^{\circ} \mathrm{C}\right) ; \mathrm{c} 2=\operatorname{Suhu} 750^{\circ} \mathrm{C}\left(\right.$ Temperature $\left.750^{\circ} \mathrm{C}\right) ; \mathrm{c} 3$ $=$ Suhu $850^{\circ} \mathrm{C}\left(\right.$ Temperature $\left.850^{\circ} \mathrm{C}\right)$.
\end{abstract}

\section{KadarZat Terbang}

Hasil analisa sidik ragam (Tabel 2) menunjukkan bahwa antara bahan baku, konsentrasi kimia dan suhu memberikan pengaruh nyata terhadap kadar zat terbang yang dikandung arang aktif. Pada Tabel 3 terlihat bahwa kadar zat terbang tertinggi (12,98\%) dimiliki arang tempurung kelapa sawit yang diaktivasi dengan konsentrasi $\mathrm{H}_{3} \mathrm{PO}_{4} 7,5 \%$ pada suhu $850^{\circ} \mathrm{C}$ (a1b1c3) dan kadar zat terbang terendah $(9,14 \%)$ terdapat pada arang tempurung kelapa sawit yang diaktivasi dengan konsentrasi $\mathrm{H}_{3} \mathrm{PO}_{4} 12,5 \%$ pada suhu $750^{\circ} \mathrm{C}$ (a1b3c2), sedangkan untuk arang aktif serbuk gergaji campuran kayu, kadar zat terbang tertinggi $(15,23 \%)$ terdapat pada arang aktif yang dihasilkan dari perlakuan aktivasi dengan menggunakan konsentrasi $\mathrm{H}_{3} \mathrm{PO}_{4} 10 \%$ dan suhu $650^{\circ} \mathrm{C}(\mathrm{a} 2 \mathrm{~b} 2 \mathrm{c} 1)$, sedangkan terendah $(10,70 \%)$ dengan menggunakan konsentrasi $\mathrm{H}_{3} \mathrm{PO}_{4} 10 \%$ dan suhu $850^{\circ} \mathrm{C}$ (a2b2c3). Kadar zat terbang yang dikandung arang aktif tempurung kelapa sawit maupun serbuk kayu gergajian campuran memenuhi kualitas kadar zat terbang arang aktif yang ditetapkan oleh Standar Nasional Indonesia yaitu maksimum 25\% (Tabel3). 
Pada Tabel 3 terlihat bahwa untuk menghasilkan arang aktif yang mengandung zat terbang rendah $(9,14 \%)$ dari arang tempurung kelapa sawit adalah dengan cara mengaktivasi arang dengan konsentrasi $\mathrm{H}_{3} \mathrm{PO}_{4} 7,5 \%$ pada suhu $850^{\circ} \mathrm{C}$ (a1b1c3), sedangkan untuk serbuk gergaji campuran kayu menggunakan konsentrasi $\mathrm{H} 3 \mathrm{PO} 410 \%$ pada suhu $650^{\circ} \mathrm{C}$ yaitu a2b2c1 (Gambar 4).

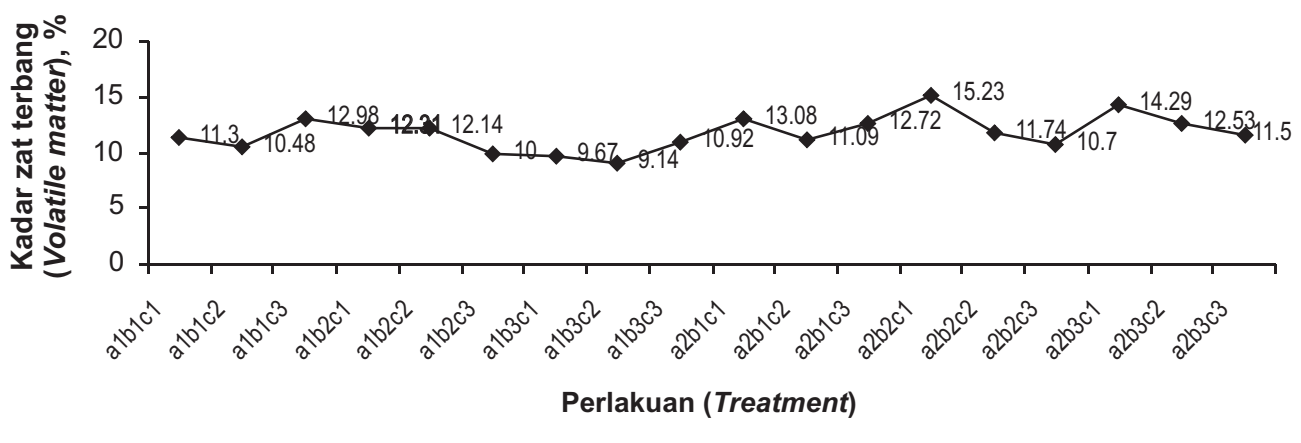

\title{
Gambar 4. Interaksi antara perlakuan dengan zat terbang Figure 4. Interaction betwen treatments and volatile matter content
}

\begin{abstract}
Keterangan (Remarks) : a1 = Arang tempurung kelapa sawit (Charcoal from oil palm shell); $\mathrm{a} 2=$ Arang serbuk kayu gergajian campuran (Charcoal from mixture of sawdust); b1 $=$ Konsentrasi $\mathrm{H}_{3} \mathrm{PO}_{4}$ 7,5\% (Concentrations phosphoric acid 7.5\%); b2 = Konsentrasi $\mathrm{H}_{3} \mathrm{PO}_{4} 10 \%$ (Concentrations phosphoric acid 10\%); b3 = Konsentrasi $\mathrm{H}_{3} \mathrm{PO}_{4} 12,5 \%$ (Concentrations phosphoric acid 12.5\%), $\mathrm{c} 1=$ Suhu $650^{\circ} \mathrm{C}\left(\right.$ Temperature $\left.650^{\circ} \mathrm{C}\right) ; \mathrm{c} 2=\operatorname{Suhu} 750^{\circ} \mathrm{C}\left(\right.$ Temperature $\left.750^{\circ} \mathrm{C}\right) ; \mathrm{c} 3=\mathrm{Suhu}$ $850^{\circ} \mathrm{C}$ (Temperature $\left.850^{\circ} \mathrm{C}\right)$.
\end{abstract}

\section{E. Kadar Karbon}

Hasil analisa sidik ragam (Tabel 2) menunjukkan bahwa pengaruh interaksi bahan baku, konsentrasi bahan kimia dan suhu terhadap kadar karbon adalah nyata.

Penentuan kadar karbon arang aktif bertujuan untuk mengetahui kandungan karbon setelah proses pengarangan. Hasil penelitian menunjukkan bahwa arang tempurung kelapa sawit yang diaktivasi dengan konsentrasi $\mathrm{H}_{3} \mathrm{PO}_{4} 12,5 \%$ pada suhu $650^{\circ} \mathrm{C}$ (a1b3c1) menghasilkan kadar karbon tertinggi sebesar 86,62\% dan kadar karbon terendah sebesar $81,06 \%$ dimiliki arang tempurung kelapa sawit yang diaktivasi dengan konsentrasi H3PO4 $7,5 \%$ pada suhu $850^{\circ} \mathrm{C}$ (a1b1c3). Sedangkan untuk arang aktif dari arang serbuk gergaji campuran kayu yang mengandung kadar karbon tertinggi sebesar 81,41\% diperoleh dari arang yang diaktivasi dengan konsentrasi $\mathrm{H}_{3} \mathrm{PO}_{4} 7,5 \%$ pada suhu $750^{\circ} \mathrm{C}$ (a2b1c2), dan kadar karbon terendah sebesar $73,67 \%$ adalah dengan konsentrasi $\mathrm{H}_{3} \mathrm{PO}_{4} 7,5 \%$ pada suhu $850^{\circ} \mathrm{C}$ (a2b1c3). Rendahnya kadar karbon yang dikandung arang aktif, selain disebabkan tingginya kadar zat terbang dan kadar abu (Tabel.3), juga disebabkan oleh lamanya waktu reaksi 
sehingga zat kimia yang bereaksi semakin banyak sehingga jumlah karbon yang tersisa semakin sedikit (Pari, 1995).

Dari hasil uji lanjut menunjukkan bahwa kombinasi perlakuan aktivasi yang paling baik untuk arang tempurung kelapa sawit agar menghasilkan arang aktif yang mengandung kadar karbon yang memenuhi persyaratan SNI adalah menggunakan konsentrasi $\mathrm{H}_{3} \mathrm{PO}_{4} \quad 12,5 \%$ dengan suhu $650^{\circ} \mathrm{C}(\mathrm{a} 1 \mathrm{~b} 3 \mathrm{c} 1)$, sedangkan untuk serbuk gergaji campuran kayu, menggunakan $\mathrm{H} 3 \mathrm{PO} 47,5 \%$ dengan suhu $750^{\circ} \mathrm{C}(\mathrm{a} 2 \mathrm{~b} 1 \mathrm{c} 2)$.

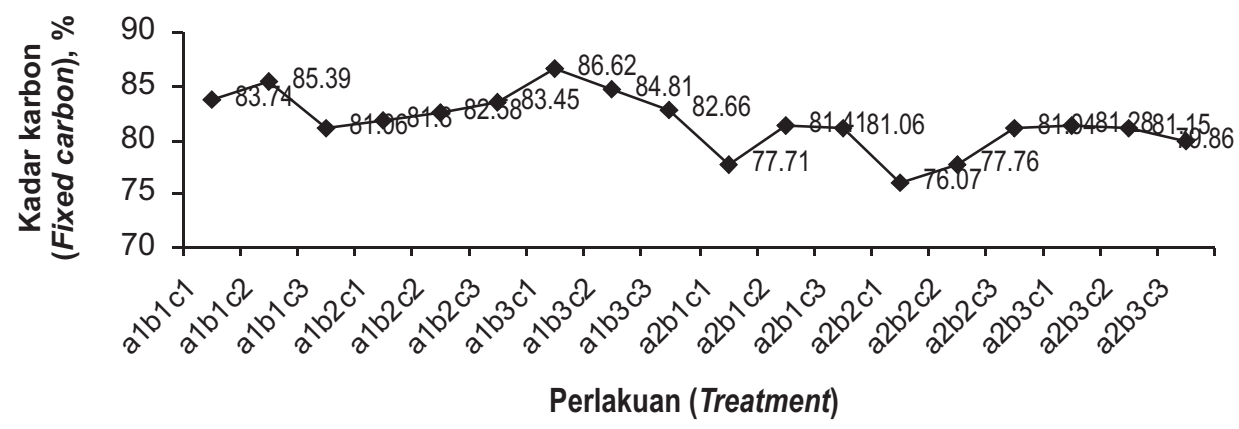

\author{
Gambar 5. Interaksi antara perlakuan dengan kadar karbon \\ Figure 5. Interaction betwen treatments and fixed carbon content
}

Keterangan (Remarks) $: \quad$ a1 = Arang tempurung kelapa sawit (Charcoal from oil palm shell); a2 = Arang serbuk kayu gergajian campuran (Charcoal from mixture of sawdust); b1 = Konsentrasi $\mathrm{H}_{3} \mathrm{PO}_{4}$ 7,5\% (Concentrations phosphoric acid 7.5\%); b2 = Konsentrasi $\mathrm{H}_{3} \mathrm{PO}_{4} 10 \%$ (Concentrations phosphoric acid 10\%); b3 = Konsentrasi $\mathrm{H}_{3} \mathrm{PO}_{4} 12,5 \%$ (Concentrations phosphoric acid 12.5\%), $\mathrm{c} 1=\operatorname{Suhu} 650^{\circ} \mathrm{C}\left(\right.$ Tem-perature $\left.650^{\circ} \mathrm{C}\right) ; \mathrm{c} 2=\operatorname{Suhu} 750^{\circ} \mathrm{C}\left(\right.$ Temperature $\left.750^{\circ} \mathrm{C}\right) ; \mathrm{c} 3=\mathrm{Suhu}$ $850^{\circ} \mathrm{C}$ (Temperature $\left.850^{\circ} \mathrm{C}\right)$.

\title{
F. Daya Serap Arang Aktif Terhadap Benzena
}

Analisa sidik ragam menunjukkan bahwa pengaruh interaksi antara bahan baku, konsentrasi H3PO4 dan suhu adalah nyata terhadap daya serap arang aktif (Tabel 2).

Benzena merupakan molekul yang berukuran kecil dan mudah menguap pada suhu ruang, sehingga benzena digunakan untuk menguji kemampuan arang aktif dalam menyerap gas. Daya serap arang aktif tempurung kelapa sawit terhadap benzena tertinggi $(41,10 \%)$ dimiliki arang tempurung kelapa sawit aktif yang diaktivasi dengan konsentrasi $\mathrm{H}_{3} \mathrm{PO}_{4} 10 \%$ pada suhu $850^{\circ} \mathrm{C}(\mathrm{a} 1 \mathrm{~b} 2 \mathrm{c} 3)$, dan daya serap terendah $(26,20 \%)$ dengan konsentrasi $\mathrm{H}_{3} \mathrm{PO}_{4}$ $7,5 \%$ pada suhu $650^{\circ} \mathrm{C}$ (a1b1c1). Daya serap arang aktif tempurung kelapa sawit tersebut memenuhi kualitas daya serap arang aktif yang ditetapkan oleh Standard Nasional Indonesia (Anonim,1995). Sedangkan untuk serbuk gergaji campuran kayu, daya serap benzena 
tertinggi $(44,0 \%)$ terdapat pada arang aktif yang diaktivasi dengan konsentrasi $\mathrm{H}_{3} \mathrm{PO}_{4} 7,5 \%$ pada suhu $850^{\circ} \mathrm{C}(\mathrm{a} 2 \mathrm{~b} 1 \mathrm{c} 3)$ dan yang terendah $(25,6 \%)$ dengan konsentrasi $\mathrm{H}_{3} \mathrm{PO}_{4} 12,5 \%$ pada suhu $750^{\circ} \mathrm{C}(\mathrm{a} 2 \mathrm{~b} 3 \mathrm{c} 2)$.

Rendahnya daya serap arang aktif terhadap benzena disebabkan adanya pori-pori yang terbentuk pada permukaan arang aktif masih banyak mengandung senyawa non karbon, sehingga gas atau uap yang diserap menjadi lebih sedikit (Pari, 1995).

Dari hasil uji lanjut menunjukkan bahwa arang tempurung kelapa sawit yang diaktivasi dengan konsentrasi $\mathrm{H}_{3} \mathrm{PO}_{4} 10 \%$ pada suhu $850^{\circ} \mathrm{C}$ (a1b2c3) memiliki daya serap arang aktif terhadap benzena terbaik. Sedangkan untuk arang aktif serbuk gergaji campuran kayu pada konsentrasi $\mathrm{H}_{3} \mathrm{PO}_{4} 7,5 \%$ dengan suhu $850^{\circ} \mathrm{C}$ (a2b1c3).
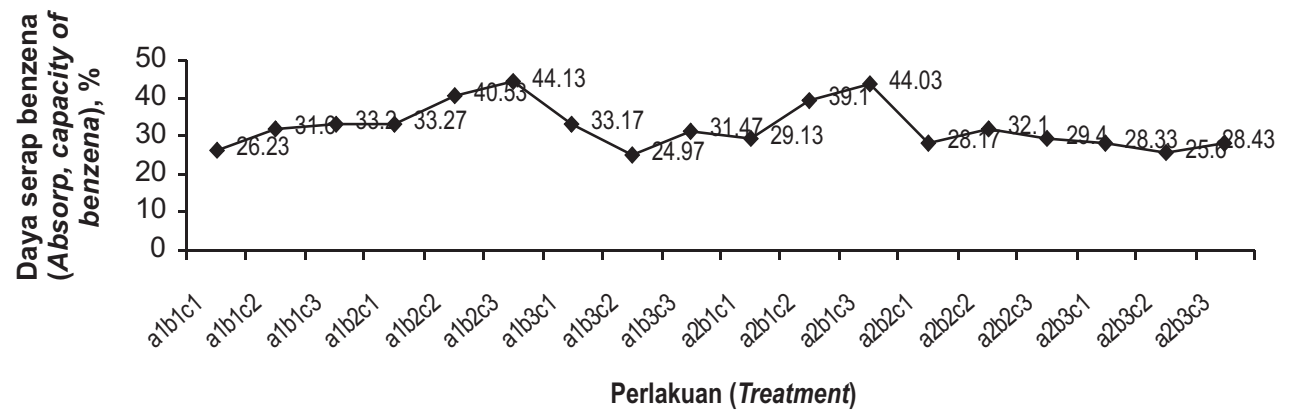

Gambar 6. Interaksi antara perlakuan dengan daya serap benzena Figure 6. Interaction between treatments and adsorption capacity of benzene

Keterangan (Remarks) : a1 = Arang tempurung kelapa sawit (Charcoal from oil palm shell); a2 = Arang serbuk kayu gergajian campuran (Charcoal from mixture of sawdust); b1 = Konsentrasi $\mathrm{H}_{3} \mathrm{PO}_{4} \quad 7,5 \%$ (Concentrations phosphoric acid 7.5\%); b2 $=$ Konsentrasi $\mathrm{H}_{3} \mathrm{PO}_{4} \quad 10 \%$ (Concentrationsphosphoric acid 10\%); b3 = Konsentrasi $\mathrm{H}_{3} \mathrm{PO}_{4} 12,5 \%$ (Concentrations phosphoric acid $12.5 \%) ; \mathrm{c} 1=\operatorname{Suhu} 650^{\circ} \mathrm{C}\left(\right.$ Temperature $\left.650^{\circ} \mathrm{C}\right) ; \mathrm{c} 2=\operatorname{Suhu} 750^{\circ} \mathrm{C}\left(\right.$ Temperature $\left.750^{\circ} \mathrm{C}\right) ; \mathrm{c} 3$ $=$ Suhu $850^{\circ} \mathrm{C}\left(\right.$ Temperature $\left.850^{\circ} \mathrm{C}\right)$.

\section{G. Daya Serap Arang Aktif Terhadap Yodium}

Hasil analisa sidik ragam (Tabel 2) menunjukkan bahwa interaksi nyata antara bahan baku, konsentrasi $\mathrm{H}_{3} \mathrm{PO}_{4}$ dan suhu berpengaruh nyata terhadap daya serap arang aktif.

Penetapan daya serap arang aktif terhadap yodium bertujuan untuk mengetahui kemampuan arang aktif untuk menyerap larutan berwarna. Hasil penelitian menunjukkan bahwa arang aktif tempurung kelapa sawit yang diaktifasi dengan konsentrasi $\mathrm{H}_{3} \mathrm{PO}_{4} 7,5 \%$ pada suhu $650^{\circ} \mathrm{C}$ (a1b1c1) memiliki daya serap yodium tertinggi yaitu sebesar 1045,3 mg/g, sedangkan terendah $(731,1 \mathrm{mg} / \mathrm{g})$ terdapat pada arang aktif tempurung kelapa sawit yang arangnya diaktivasi dengan konsentrasi $\mathrm{H}_{3} \mathrm{PO}_{4} 12,5 \%$ pada suhu $750^{\circ} \mathrm{C}$ (a1b3c2). Sedangkan 
untuk mendapatkan arang aktif dari serbuk gergaji campuran kayu yang memiliki daya serap terhadap yodium tertinggi $(1107,43 \mathrm{mg} / \mathrm{g}$ ) dan memenuhi standar JIS (Anonim, 1967) menggunakan konsentrasi $\mathrm{H}_{3} \mathrm{PO}_{4} 12,5 \%$ pada suhu $850^{\circ} \mathrm{C}(\mathrm{a} 2 \mathrm{~b} 3 \mathrm{c} 3)$, dan daya serap arang aktif terhadap yodium terendah $(749,5 \mathrm{mg} / \mathrm{g})$ terdapat pada proses aktivasi dengan menggunakan konsentrasi $\mathrm{H}_{3} \mathrm{PO}_{4} 10 \%$ pada suhu $650^{\circ} \mathrm{C}(\mathrm{a} 2 \mathrm{~b} 2 \mathrm{c} 1)$.

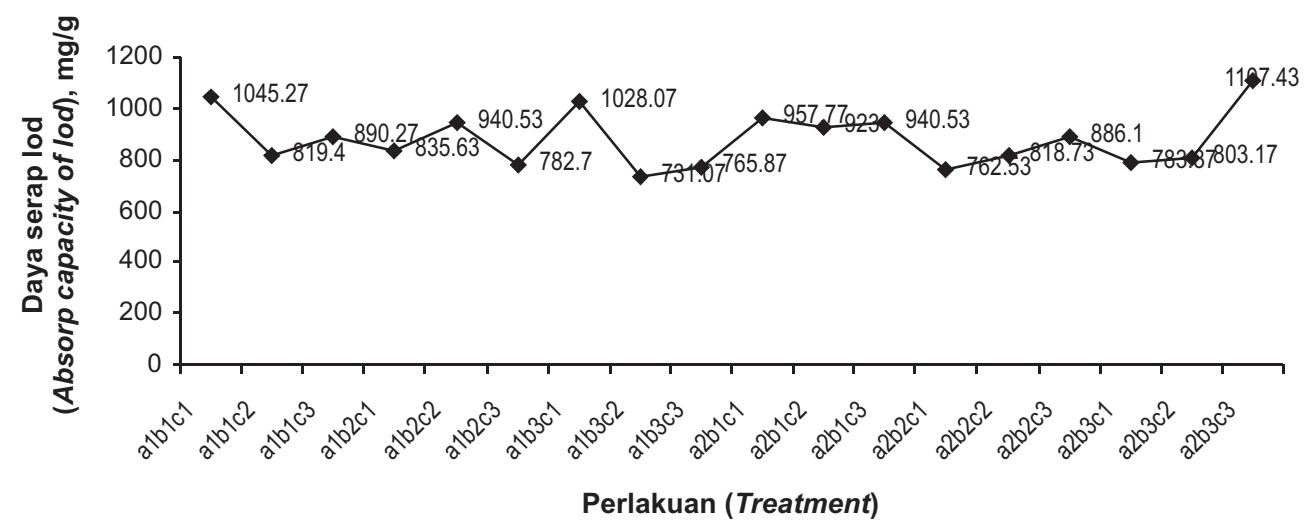

Gambar 7. Interaksi antara perlakuan dengan daya serap yodium Figure 7. Interaction betwen treatments and adsorption capacity of iodine

Keterangan (Remarks): a1 = Arang tempurung kelapa sawit (Charcoal from oil palm shell); a2 = Arang serbuk kayu gergajian campuran (Charcoal from mixture of sawdust); b1 $=$ Konsentrasi $\mathrm{H}_{3} \mathrm{PO}_{4}$ 7,5\% (Concentrations phosphoric acid 7.5\%); b2 = Konsentrasi $\mathrm{H}_{3} \mathrm{PO}_{4} 10 \%$ (Concentrations phosphoric acid 10\%); b3 = Konsentrasi $\mathrm{H}_{3} \mathrm{PO}_{4} 12,5 \%$ (Concentrations phosphoric acid 12.5\%); $\mathrm{c} 1=\mathrm{Suhu} 650^{\circ} \mathrm{C}\left(\right.$ Temperature $\left.650^{\circ} \mathrm{C}\right) ; \mathrm{c} 2=\operatorname{Suhu} 750^{\circ} \mathrm{C}\left(\right.$ Temperature $\left.750^{\circ} \mathrm{C}\right) ; \mathrm{c} 3=\mathrm{Suhu}$ $850^{\circ} \mathrm{C}\left(\right.$ Temperature $\left.850^{\circ} \mathrm{C}\right)$.

Daya serap arang aktif terhadap yodium yang tinggi disebabkan besarnya diameter poripori arang aktif karena senyawa hidrokarbon yang terdapat pada permukaan arang aktif telah banyak keluar pada saat aktivasi. Hal ini terjadi karena pergeseran pelat-pelat karbon yang menyebabkan terdorongnya residu-residu hidrokarbon (Pari, 1995). 
Tabel 4. Daya serap Arang aktif terhadap yodium dan benzena.

Table 4. Adsorption capacity of activated charcoal on iodine and benzene

\begin{tabular}{|c|c|c|c|c|}
\hline \multirow{2}{*}{$\begin{array}{l}\text { Bahan baku } \\
\text { (Raw materials) }\end{array}$} & \multirow{2}{*}{$\begin{array}{c}\mathrm{H}_{3} \mathrm{PO}_{4} \\
(\%)\end{array}$} & \multirow{2}{*}{$\begin{array}{c}\text { Suhu } \\
\text { (Temperature) } \\
\left({ }^{\circ} \mathrm{C}\right)\end{array}$} & \multicolumn{2}{|c|}{ Daya serap (Absorption capacity) } \\
\hline & & & Yodium $(\mathrm{mg} / \mathrm{g})$ & Benzena $(\%)$ \\
\hline $\begin{array}{l}\text { Arang tempurung kelapa } \\
\text { sawit (Charcoal from } \\
\text { oil palm shell) }\end{array}$ & 7,5 & $\begin{array}{l}650 \\
750 \\
850\end{array}$ & $\begin{array}{r}1.045,27 \\
819,40 \\
890,27\end{array}$ & $\begin{array}{l}26,23 \\
31,60 \\
33,20\end{array}$ \\
\hline & 10 & $\begin{array}{l}650 \\
750 \\
850\end{array}$ & $\begin{array}{l}835,63 \\
940,53 \\
782,70\end{array}$ & $\begin{array}{l}33,27 \\
40,53 \\
44,13\end{array}$ \\
\hline & 12,5 & $\begin{array}{l}650 \\
750 \\
850\end{array}$ & $\begin{array}{r}1.028,07 \\
731,07 \\
765,87\end{array}$ & $\begin{array}{l}33,17 \\
24,97 \\
31,47\end{array}$ \\
\hline $\begin{array}{l}\text { Arang serbuk gergaji } \\
\text { campuran kayu (Charcoal } \\
\text { from mixture of sawdust) }\end{array}$ & 7,5 & $\begin{array}{l}650 \\
750 \\
850\end{array}$ & $\begin{array}{l}957,77 \\
923,00 \\
940,53\end{array}$ & $\begin{array}{l}29,13 \\
39,10 \\
44,03\end{array}$ \\
\hline & 10 & $\begin{array}{l}650 \\
750 \\
850\end{array}$ & $\begin{array}{l}762,53 \\
818,73 \\
886,10\end{array}$ & $\begin{array}{l}28,17 \\
32,10 \\
29,40\end{array}$ \\
\hline & 12,5 & $\begin{array}{l}650 \\
750 \\
850\end{array}$ & $\begin{array}{r}783,37 \\
803,17 \\
1.107,43\end{array}$ & $\begin{array}{l}28,33 \\
25,60 \\
28,43\end{array}$ \\
\hline $\begin{array}{l}\text { Standar Nasional } \\
\text { Indonesia (Indonesian } \\
\text { National Standard) }\end{array}$ & - & - & 750 & 25 \\
\hline $\begin{array}{l}\text { Standar Jepang (Japanese } \\
\text { Industrial Standard) }\end{array}$ & - & - & 1.050 & 35 \\
\hline
\end{tabular}




\section{H. Penyerapan Kation dari Air Sumur}

Arang aktif tempurung kelapa sawit yang digunakan untuk menyerap kation pada air sumur adalah arang aktif yang memiliki daya serap yodium tertinggi (1045,27 mg/g) yang diperoleh dari proses aktivasi dengan $\mathrm{H}_{3} \mathrm{PO}_{4} \quad 12,5 \%$ pada suhu $650^{\circ} \mathrm{C}$ (a1b3c1), sedangkan untuk arang aktif serbuk gergaji campuran kayu digunakan arang aktif dari proses aktivasi dengan $\mathrm{H}_{3} \mathrm{PO}_{4} 7,5 \%$ pada suhu $850^{\circ} \mathrm{C}$ (a2b1c3). Hasil pengamatan secara visual terlihat air sumur yang semula berwarna kuning $(\mathrm{pH} 7,02)$ setelah diberikan arang aktif dari tempurung kelapa sawit pH-nya menjadi 8,05 dan air sumur berwarna bening. Demikian pula air sumur yang dijernihkan dengan arang aktif dari serbuk gergajian kayu campuran $\mathrm{pH}$-nya meningkat menjadi 8,21 dan berwarna bening. Peningkatan nilai $\mathrm{pH}$ air disebabkan oleh adanya kation dalam arang aktif yang terlarut ke dalam air, selama proses pembuatan arang aktif yang menggunakan metode perendaman dengan larutan $\mathrm{H}_{3} \mathrm{PO}_{4}$. Hasil pengukuran $\mathrm{pH}$ ini masih berada pada kisaran $\mathrm{pH}$ yang disyaratkan untuk air bersih menurut Departemen Kesehatan yaitu pH 6,5 - 9,0 (Anonim, 1990).

Kandungan besi $(\mathrm{Fe})$ dan seng $(\mathrm{Zn})$ pada kondisi awal sebelum diberikan arang aktif yaitu $5,012 \mathrm{mg} / 1$ dan $0,046 \mathrm{mg} / 1$. Setelah diberikan arang aktif, kandungan kedua jenis logam tersebut tidak terdeteksi (100\% teradsorpsi) yaitu menjadi $0,0 \mathrm{mg} / 1$ untuk Fe dan $0,046 \mathrm{mg} / \mathrm{l}$ untuk Zn. Sedangkan untuk kandungan mangan $(\mathrm{Mn})$ tidak memenuhi persyaratan untuk air minum maupun air bersih yang diperbolehkan Departemen Kesehatan (Anonim, 1990) karena kadar Mn nya lebih dari 0,5 mg/l. Hal ini selain disebabkan oleh bentuk pori yang asimetris juga oleh pori-pori arang aktif yang telah penuh terisi dengan kation-kation yang lain, sehingga tidak dapat menyerap Mn secara maksimal.

Tabel 5. Sifat fisiko-kimia air sumur

Table 5. Pbysico-chemical properties of ground water

\begin{tabular}{|l|c|c|c|c|c|c|}
\hline \multirow{1}{*}{ Parameter } & $\begin{array}{c}\text { Satuan } \\
\text { (Unit) }\end{array}$ & $\begin{array}{c}\text { Kadar maks. yang diperbolehkan } \\
\text { sesuai Permenkes RI No. 416/ } \\
\text { Menkes/PER/IX/1990 1)* }\end{array}$ & \multicolumn{3}{|c|}{$\begin{array}{c}\text { Air sumur } \\
\text { (Ground water) }\end{array}$} \\
\hline & & $\begin{array}{c}\text { Air minum } \\
\text { (Drinking water) }\end{array}$ & $\begin{array}{c}\text { Air bersih } \\
\text { (Fresh water) }\end{array}$ & $\begin{array}{c}\text { Awal } \\
\text { (Initia) }\end{array}$ & $\mathrm{A}^{1}$ & $\mathrm{~B}^{2}$ \\
\hline Warna (Color) & - & - & - & $\begin{array}{c}\text { Kuning } \\
\text { (Yellow) }\end{array}$ & - & - \\
\hline $\mathrm{pH}$ & - & $6,5-8,5$ & $6,5-9,0$ & 7,02 & 8,05 & 8,21 \\
\hline Besi (Fe) & $\mathrm{Mg} / \mathrm{I}$ & 0,2 & 1,0 & 5,012 & $\mathrm{Ttd}$ & $\mathrm{Ttd}$ \\
\hline Seng (Zn) & $\mathrm{Mg} / \mathrm{I}$ & 5,0 & 15,0 & 0,046 & $\mathrm{Ttd}$ & $\mathrm{Ttd}$ \\
\hline Mangan (Mn) & $\mathrm{Mg} / \mathrm{I}$ & 0,1 & 0,5 & 7,812 & 5,432 & 6,023 \\
\hline
\end{tabular}

Keterangan (Remarks): A1: Air dijernihkan menggunakan arang aktif dari tempurung kelapa sawit (Water was purified using activated charcoal oil palm sheld); B2 : Air dijernihkan menggunakan arang aktif dari serbuk gergaji campuran kayu (Water was purified using activated charcoal from mixture of wood sawdust); Ttd :Tidak terdeteksi (Undetected); 1)*: Anonim, 1990. 


\section{KESIMPULAN}

Arang aktif yang dibuat dari arang serbuk gergaji campuran kayu yang diaktivasi dengan konsentrasi $\mathrm{H}_{3} \mathrm{PO}_{4} 12,5 \%$ pada suhu $850^{\circ} \mathrm{C}$ menghasilkan rendemen arang aktif $(63,3 \%)$, kadar air $(7,90 \%)$, kadar abu $(8,04 \%)$, kadar zat terbang $(11,50 \%)$, kadar karbon terikat $(79,86 \%)$, daya serap benzene $(28,43 \%)$, dan daya serap terhadap yodium $(1107,43$ $\mathrm{mg} / \mathrm{g})$ yang memenuhi standar SNI dan JIS.

Arang aktif dibuat dari arang tempurung kelapa sawit yang diaktivasi pada suhu $650^{\circ} \mathrm{C}$ dengan konsentrasi H3PO4 7,5\% menghasilkan rendemen arang aktif (80\%), kadar air $(5,30 \%)$, kadar abu (5,44\%), kadar zat terbang (11,30\%), kadar karbon terikat $(83,74 \%)$, daya serap terhadap benzene $(26,23 \%)$, dan daya serap terhadap yodium $(1.045,27 \mathrm{mg} / \mathrm{g})$ yang memenuhi standar SNI.

Arang aktif dari arang tempurung kelapa sawit dan arang serbuk gergaji campuran kayu tersebut di atas dapat menyerap kation Fe dan $\mathrm{Zn}$ yang dikandung air sumur dengan sempurna (100\%), tetapi tidak dapat menyerap kation Mn dengan sempurna.

\section{DAFTAR PUSTAKA}

Anonim. 1967. Japanese Industrial Standard K 1474. Testing method for powdered activated carbon. Japanese Standard Association. Tokyo.

Anonim. 1990. Daftar persyaratan kualitas air minum. Departemen Kesehatan. Jakarta.

Anonim. 1995. Arang aktif teknis. Standar Nasional Indonesia (SNI) 06-3730-1995. Jakarta.

Hendra, D. dan G. Pari. 1999. Pembuatan arang aktif dari tandon kosong kelapa sawit. Buletin Penelitian Hasil Hutan. 17(2):133-122. Bogor.

Pari, G. 1995. Pembuatan dan karakterristik arang aktif dari batubara. Tesis Program Magister Kimia Institut Teknologi Bandung. Bandung. Tidak diterbitkan.

Sudjana, M. A. 1992. Metode Statistika. Edisi kelima. Tarsito. Bandung. 